\title{
The first "osteolepiform" tetrapodomorph (Sarcopterygii) from the Paleozoic sequences of the Moravian Karst (Czech Republic)
}

\author{
Hedvika POUKAROVÁ ${ }^{1,2, *}$ and Tomáš WEINER ${ }^{1,2}$ \\ 1 Masaryk University, Department of Geological Sciences, Faculty of Science, Kotlářská 2, 61137 Brno, Czech Republic \\ 2 Institute of Geology of the Czech Academy of Sciences, v.v.i., Rozvojová 269, 16500 Prague 6, Czech Republic
}

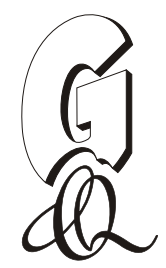

\begin{abstract}
Poukarová, H., Weiner, T., 2016. The first "osteolepiform" tetrapodomorph (Sarcopterygii) from the Paleozoic sequences of the Moravian Karst (Czech Republic). Geological Quarterly, 60 (3): 737-745, doi: 10.7306/gq.1301

The first tetrapodomorph specimen from the Paleozoic sequences of the Moravian Karst (Moravo-Silesian Basin, Bohemian Massif, Czech Republic) is described. The well-preserved, cosmine-covered lateral extrascapular bone comes from the Upper Devonian (Famennian) hemipelagic Křtiny Limestone of the Lišeň Formation. The affinity to the "osteolepiforms" is inferred from the cosmine histology and morphological features of the bone. Assignment to the Megalichthyiformes seems most probable. The associated fauna, e.g., clymenids, orthocone nautiloids, thin shelled bivalves, trilobites and crinoids, clearly demonstrate a marine environment.
\end{abstract}

Key words: Tetrapodomorpha, "Osteolepiformes", cosmine, Famennian, Moravo-Silesian Basin, Moravian Karst.

\section{INTRODUCTION}

Sarcopterygian fish are especially interesting because of their close relation to the tetrapods (Rosen et al., 1981; Thomson, 1993; Cloutier and Ahlberg, 1996; Ahlberg and Johanson, 1998; Long and Gordon, 2004; Clack, 2006). The integumentary skeleton of the sarcopterygians is plesiomorphically characterized by cosmine (e.g., Sire et al., 2009). This unique tissue complex consists of a canal system enclosed in an enamel/enameloid-coated single layer of odontodes (Gross, 1956; Thomson, 1975, 1977; Meinke, 1984; Zhu et al., 2006) and an uppermost part of spongy bone (Thomson, 1975, 1977; Borgen, 1992). Flask-shaped pore-canals, which open to the surface by minute pores, are connected by mesh-canals to each other and by cross-canals to the pulp cavities (Gross, 1956; Thomson, 1975, 1977; Meinke, 1984). The canal system is continuous with the vascular canals of the underlying spongiosa (Thomson, 1977; Borgen, 1992) and is supposed to possess vascular functions involved in the deposition of dentine and enamel/enameloid (Bemis and Northcutt 1992; Borgen, 1992; Zhu et al., 2006). The cosmine cover in crown sarcopterygians is significant for its uniphase deposition (Zhu et al., 2006, 2010). Seasonal resorption and redeposition of this special tissue complex is supposed to allow growth of the animal (e.g., Westoll, 1936; Ørvig, 1969; Thomson, 1975, 1977; Borgen, 1989, 1992; Fox et al., 1995).

\footnotetext{
* Corresponding author, e-mail: h.poukarova@seznam.cz

Received: February 1, 2016; accepted: April 7, 2016; first published online: June 28, 2016
}

To date, the Devonian and Lower Carboniferous sequences of the Moravian Karst (Moravo-Silesian Basin, Bohemian Massif, Czech Republic; see Figs. 1A, B and 2) have provided poor evidence of sarcopterygian fish comprising onychodontiforms only (see Ginter, 1991; Smutná, 1994, 1996; Kumpan, 2013).

Recently, a cosmine-covered dermal bone was obtained from a small abandoned quarry situated in the southern part of the Moravian Karst near the road connecting Brno-Líšeň and Ochoz at Brno (Fig. 1C). This quarry might correspond to a fossil site described by Rzehak (1910). A section about two metres thick is composed of the Famennian hemipelagic Krttiny Limestone of the Líšeň Formation (Weiner and Kalvoda, 2013). This strongly condensed succession (Weiner and Kalvoda, 2016) corresponds to the Hostěnice facies development (Rez et al., 2011). The bone comes from a darker grey bioclastic limestone (Fig. 3) developed closely above the black limestone lenses of the Lower Annulata Event (Upper Palmatolepis rugosa trachytera conodont Zone, see Weiner and Kalvoda, 2016). The presence of Polygnathus styriacus Hinde, 1900 in the grey bioclastic limestone (microfacies F sensu Weiner and Kalvoda, 2016) might indicate the base of the Lower Palmatolepis perlobata postera conodont Zone (e.g., Hartenfels, 2011, Weiner and Kalvoda, 2016). Conodonts indicate the palmatolepid-polygnathid biofacies (Weiner, 2013; Weiner and Kalvoda, 2016), which is generally supposed to occupy the upper to middle part of a basin slope environment (e.g., Kalvoda et al., 1999: 144; Fig. 3). The microfacies corresponding to wackestone to packstone was interpreted as deposited above or slightly below storm wave base (microfacies F sensu Weiner and Kalvoda, 2016). The layer contains a rich fauna including ammonoids, orthocone nautiloids, thin-shelled bivalves, ostracods, crinoids and trilobites (Weiner and Kalvoda, 2013, 


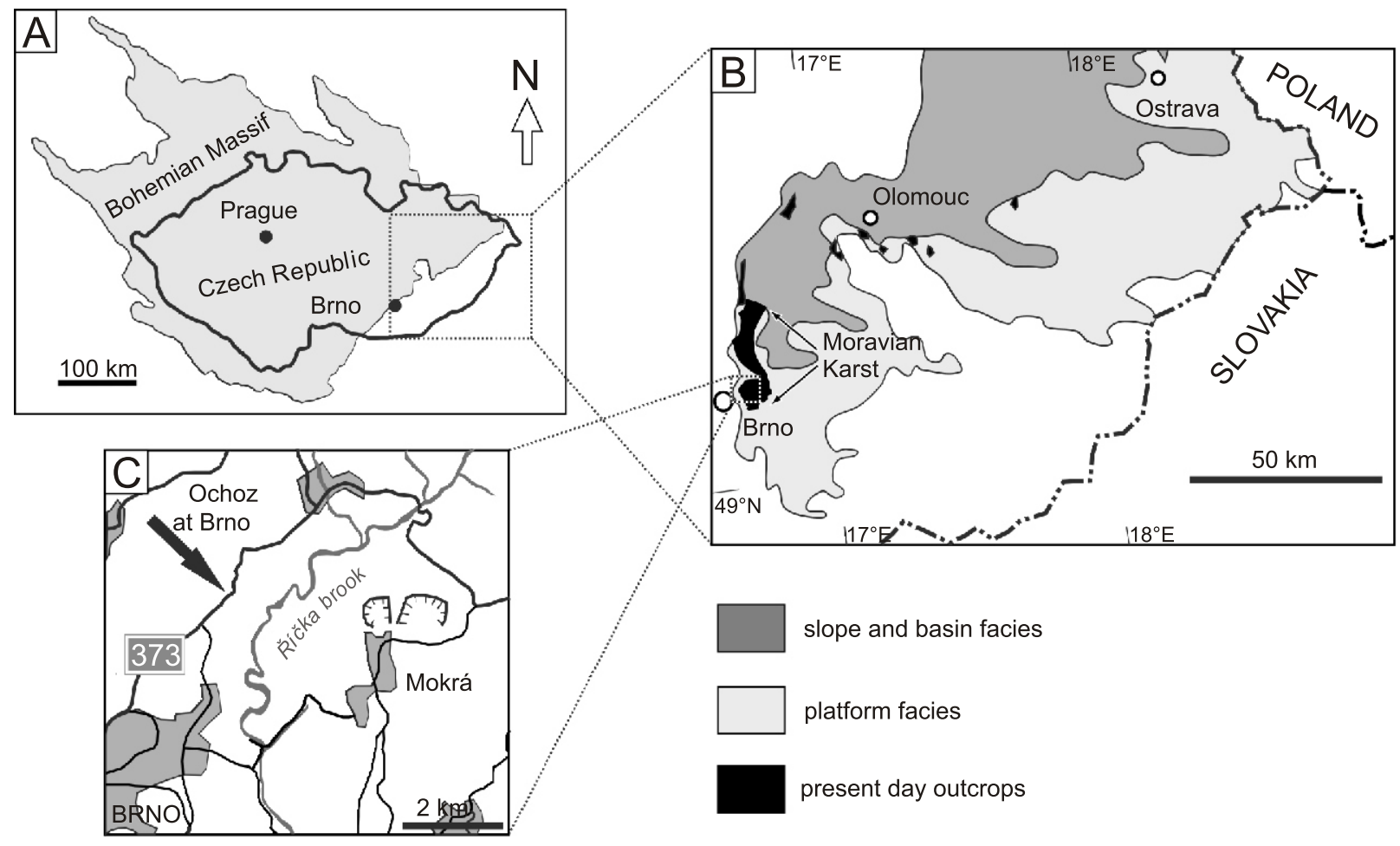

Fig. 1A - position of the area studied in the Czech Republic and the Bohemian Massif; B - simplified map of the Upper Devonian carbonate platform of the Moravo-Silesian Basin in the subsurface and at outcrop, modified after Bábek et al. (2007); C - geographic position of the locality studied (marked by a black arrow)

Horákov facies

Hostěnice facies

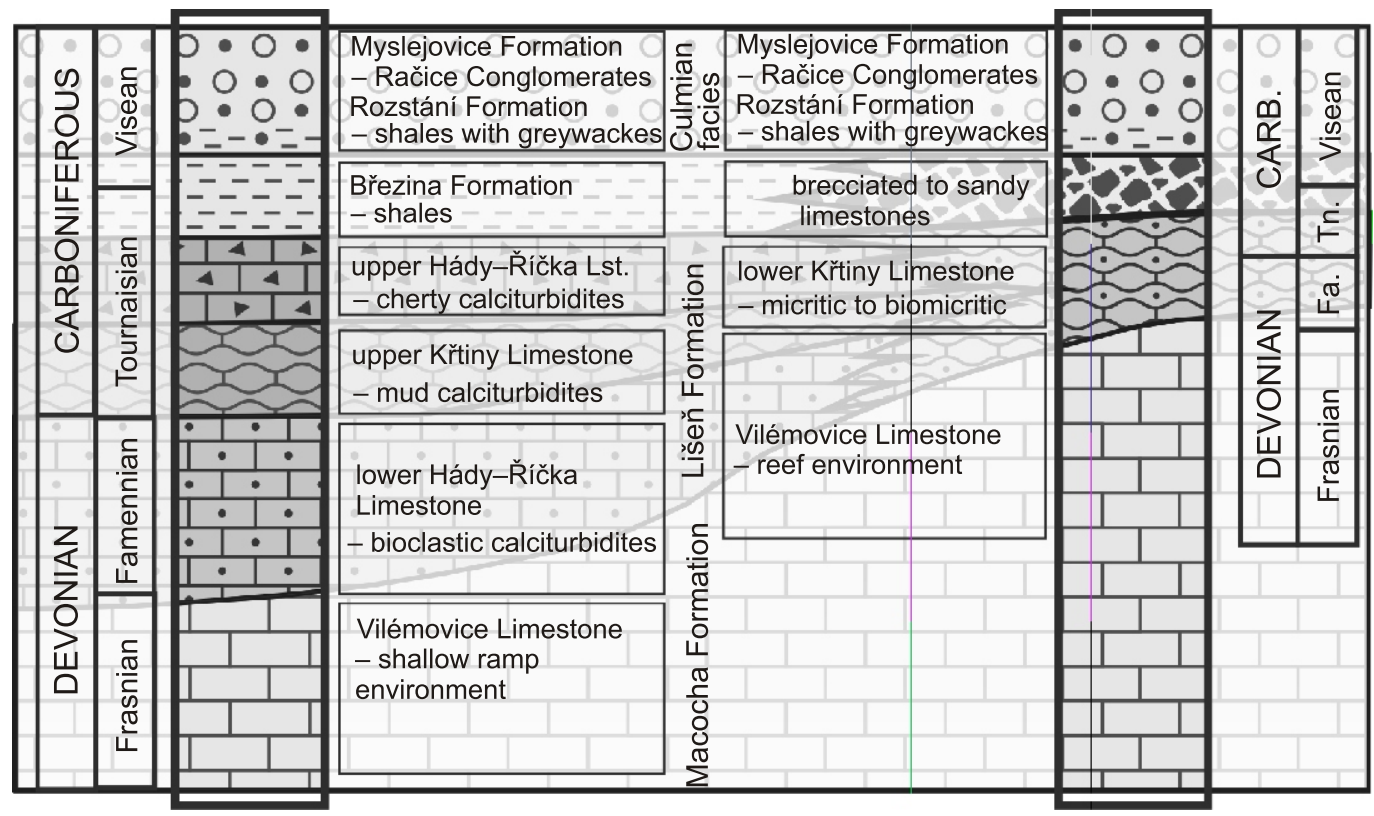

Fig. 2. Stratigraphic scheme of the southern part of the Moravian Karst (after Kalvoda, 1996 in Rez et al., 2011)

Lst. - limestone, Fa. - Famennian, Tn. - Tournaisian 

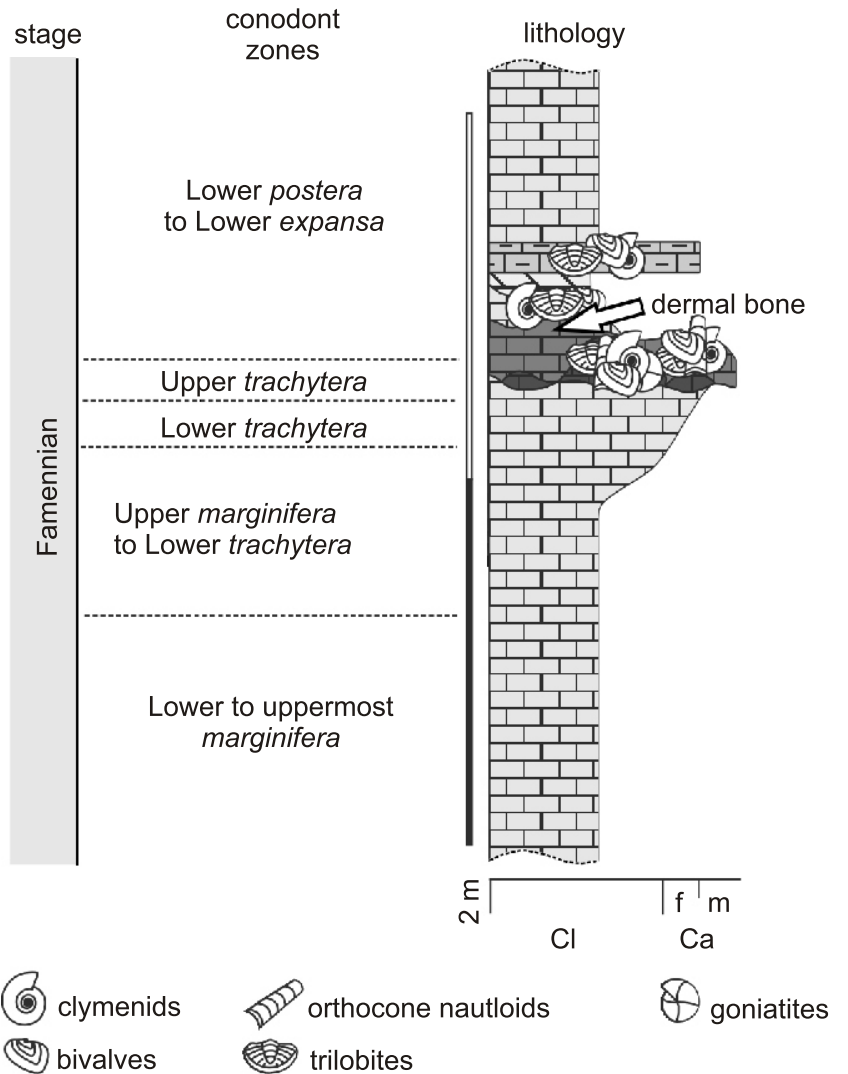

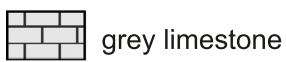

darker grey bioclastic limestone

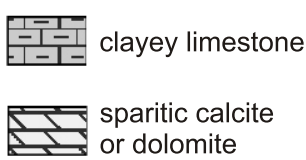

black to dark grey limestone of the Annulata Event and drowned during the Frasnian to Late Famennian interval, and this was connected to the onset of the halfgraben sedimentation of the Líšeň Formation (Kalvoda and Melichar, 1999; Bábek et al., 2007; Kalvoda et al., 2008). In the Famennian interval, two facies developments of the Líšeň Formation may be roughly distinguished in the southern part of the Moravian Karst (Fig. 2): the Horákov facies development is characterized by relatively thick sequences of calciturbidites (Hády-Říčka Limestone), which were deposited in deeper parts of the slope and basin, whereas the Hostěnice facies development comprises condensed successions of nodular hemipelagites (Křtiny Limestone), representing a shallower environment on the bypass slope (Kalvoda et al., 1996; Rez et al., 2011).

\section{MATERIAL AND METHODS}

The cosmine-covered dermal bone is preserved together with indeterminable fish remains in the same sample. The bone is well-preserved but the cosmine surface especially is affected by numerous microcracks.

The bone, broken in the field into two parts, was mechanically prepared using a pneumatic engraving pen and subsequently chemically treated with dilute acetic acid. The small area at the crack dividing the bone into two parts was polished. Detailed photographs were taken using a Nikon SMZ 1500 binocular microscope with a Nikon DXM digital camera and NIS-Elements software. In some cases, the sample was submerged in water for better results, and in others, a coating of ammonium chloride was applied. Detailed measurements were taken using JMicroVision software (Nicolas Roduit, Switzerland). A coating of gold was applied to a small area of the cosmine surface before using scanning electron microscopy.

\section{SYSTEMATIC PART}

The stratigraphic position of the "osteolepiform" dermal bone is marked by an arrow; $\mathrm{Cl}$ - calcilutite, $\mathrm{Ca}$ - calcarenite, $\mathrm{f}$ - fine grained, $\mathrm{m}$ - medium grained; modified after Weiner and Kalvoda (2016)

2016). The insoluble residuum also yielded fish remains belonging mostly to chondrichthyans and "palaeoniscids".

The cosmine-covered bone is housed in the Collections of the Czech Geological Survey, Prague, inventory numbers HP108a and HP108b.

\section{GEOLOGICAL SETTING}

The Middle Devonian to Lower Carboniferous sequences of the Moravian Karst were deposited in the Moravo-Silesian Basin at the southern margin of Laurussia (e.g., Kalvoda et al., 2002, 2008). In a regional geological context, these sequences belong to the Moravo-Silesian zone of the Bohemian massif (Finger et al., 2000) and correspond to the Rhenohercynian zone of the Central European Variscides (Hladil et al., 1999). The Moravian Karst facies development represents one of several pre-flysch facies domains in the Moravo-Silesian Basin (e.g., Zukalová and Chlupáč, 1982; Hladil, 1992; Kalvoda et al., 2002, 2008). The carbonate platform (Macocha Formation) of the Moravian Karst development began to be progressively tectonically disintegrated

\author{
Osteichthyes Huxley, 1880 \\ Sarcopterygii Romer, 1955 \\ Rhipidistia Cope, 1887 sensu Cloutier and Ahlberg, 1996 \\ Tetrapodomorpha Ahlberg, 1991 \\ "Osteolepiformes" indet. \\ (Figs. 4A, 5 and 6)
}

Material. - One cosmine-covered right lateral extrascapular from the Krrtiny Limestone of the Lišeň Formation; Famennian (the span of the Lower postera to Lower expansa conodont Zones); "Ochoz section" (sensu Weiner and Kalvoda, 2016) between Brno and Ochoz at Brno.

D e s c ri p t i o n. - The right lateral extrascapular has a subtriangular outline and is about $2 \mathrm{~cm}$ in size. Three slightly concave overlapped areas are developed at its anterior margin. The main sensory canal passes through the middle of them. Other margins lack overlapped areas. The corner between the slightly convex lateral to posterolateral margin and the concave posteromedial margin is rounded, without a notch. The medial margin is straight to very slightly concave (Fig. 4A).

The external surface of the bone bears numerous openings for tubes leading to the main and supratemporal commissural sensory canals. The even distribution of these openings does not allow one to trace the course of the sensory canals from the bone's external surface (Fig. 4A). Nevertheless, these sensory canals with a diameter of about $0.6 \mathrm{~mm}$ are visible at a crack 
going through the bone. A short pit-line with foramina reaching approximately $57 \mu \mathrm{m}$ in diameter is developed (Figs. 4A and $5 \mathrm{~F})$. The cosmine cover is devoid of Westoll lines.

A layer approximately $0.4 \mathrm{~mm}$ thick of lamellar bone is overlain by a layer about $1.3 \mathrm{~mm}$ thick of spongy bone. Buried odontodes are absent. The enamel/enameloid coated dentine layer is about $0.14 \mathrm{~mm}$ thick and encloses the pore-canal network (Fig. 5E). The enamel/enameloid does not enter the
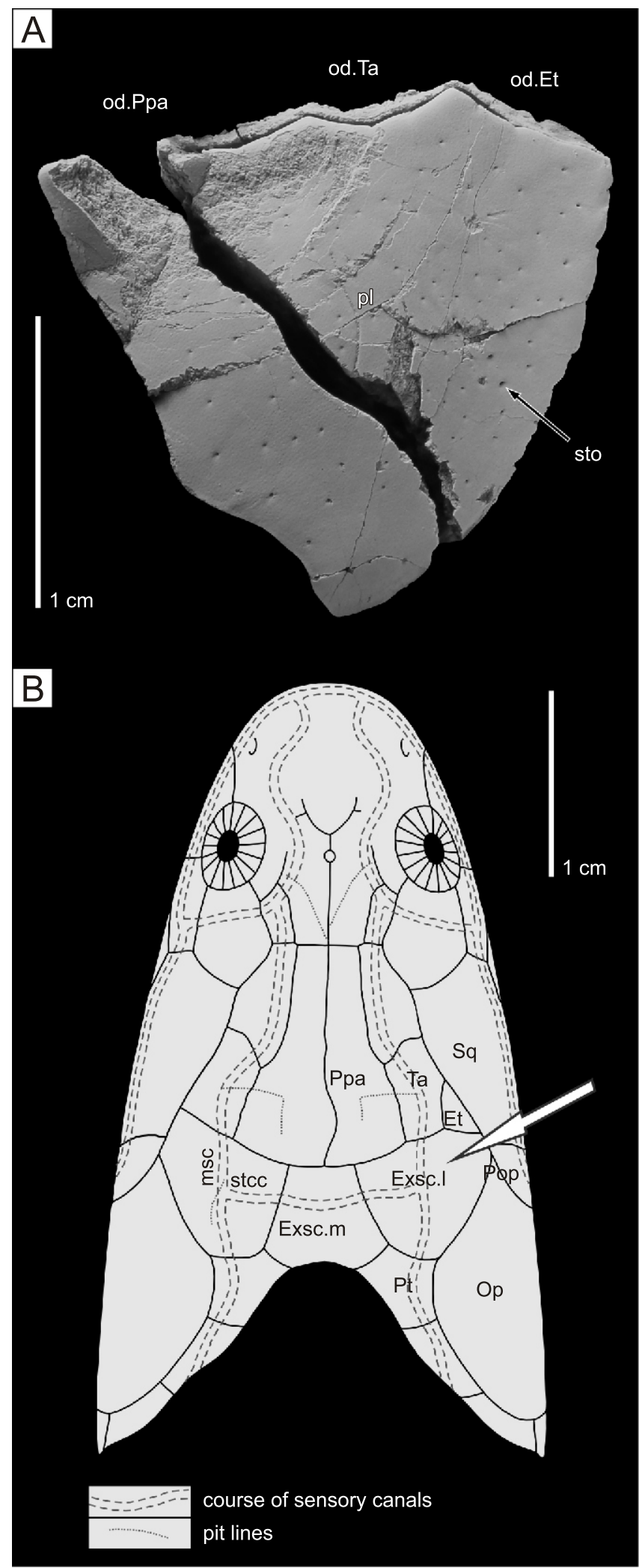

pore-canals. The shape of the pore-canals is reminiscent of an oast-house chimney. These canals reach a height of around $137 \mu \mathrm{m}$ (Fig. 5A, B, E), and their surface openings are shaped like wide funnels. The diameter of these openings reaches on average $16 \mu \mathrm{m}$ at the top (based on 70 measurements), but it can be reduced to $5 \mu \mathrm{m}$ at the base of the funnel. The distance between openings is about $153 \mu \mathrm{m}$ (140 measurements were taken). The mesh-canals reach their greatest diameter at their contact with the pore-canals, but their thickness often significantly decreases in their central part (Fig. 5B). The lower mesh-canals are missing. Bundles of roughly radially arranged dentine tubules are developed between the flask-shaped pore-canals. The orange colour of the dentine tubules might be caused by iron oxides/oxyhydroxides. The cosmine cover is brown, and its transparency enables one to observe the distribution of the pore-canals and dentine tubules, especially when the specimen is submerged in water (Fig. 5A, D, F). Using an optical microscope, a very fine pattern at the cosmine surface is apparent (Fig. 5C); nevertheless, this pattern was not clearly observed using the scanning electron microscope (see Fig. 6 showing also the details of the sensory tube opening). The partial absence of cosmine is probably caused by damage rather than by resorption.

\section{DISCUSSION}

The cosmine histology in various groups of sarcopterygian fish has been discussed e.g., by Gross (1956), Rosen et al. (1981), Meinke (1984), Schultze (1986), Chang and Smith (1992), Sire et al. (2009) and Zhu et al. (2010). The Moravian specimen possesses the combination of cosmine features including the absence of Westoll lines and buried odontodes, the enamel/enameloid not extending into the pore-canals, and the shape of the pore- and mesh-canals, which matches the conditions common in "osteolepiforms" (see Rosen et al., 1981; Meinke, 1984; Chang and Smith, 1992). The specimen also lacks the lower mesh-canals known in the Middle Devonian "osteolepiforms" such as Osteolepis Agassiz, 1835 and many early dipnoans (e.g., Dipterus Sedgwick and Murchison, 1829), which is usual in younger forms of "osteolepiform" tetrapodomorphs, e.g., Megalichthys Agassiz, 1935 or Ectosteorhachis Cope, 1880 (see Thomson, 1977). A similar shape of pore- and mesh-canals was recorded especially in Cladarosymblema Fox et al., 1995 and Megalichthys Agassiz, 1935 (see Fox et al., 1995; Gross, 1956). The diameter of the pore-canal openings in the Moravian specimen is close to the average of $10 \mu \mathrm{m}$ recorded in the "osteolepiforms" by Thomson (1977). The height of the pore-canals and their spacing also

Fig. 4A - right lateral extrascapular of "osteolepiform" tetrapodomorph from the Moravian Karst; the specimen was coated with ammonium chloride; B - position of right lateral extrascapular (arrowed) on the skull and exoskeletal shoulder girdle reconstruction of an "osteolepiform" fish (Osteolepis macrolepidotus Agassiz, 1835), modified after Jarvik (1948)

Anatomical abbreviations: Et - extratemporal, Exsc.I. - lateral extrascapular, Exsc.m. - median extrascapular, msc - main sensory canal, od.Et - area on lateral extrascapular overlapped by extratemporal, od.Ppa - area on lateral extrascapular overlapped by postparietal, od.Ta - area on lateral extrascapular overlapped by tabular, Op - operculum, pl - pit-line, Pop - preoperculum, Ppa postparietal, $\mathrm{Pt}$ - posttemporal, $\mathrm{Sq}$ - squamosal, stcc supratemporal commissural canal, sto - sensory tube opening, Ta tabular 

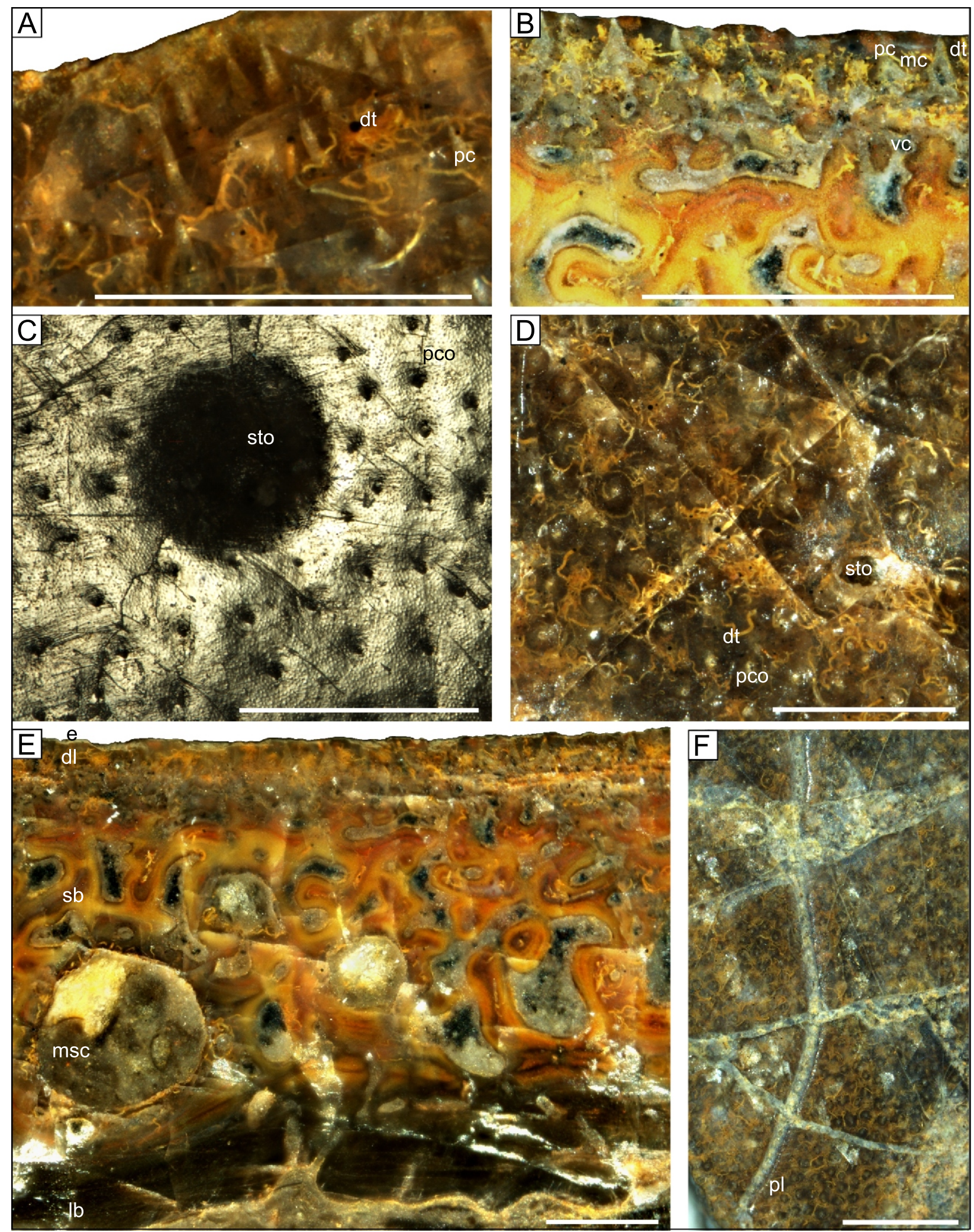

Fig. 5A - detail of the cosmine surface observed at an acute angle; B - detail of polished cross-section through the cosmine cover; C - detail of the cosmine surface showing very fine granulation; D - detail of the cosmine surface; E - polished cross-section through the dermal bone with the cosmine cover; F - detailed view of the pit-line from the cosmine surface

$\mathrm{dl}$ - dentine layer, e - enamel/enameloid, lb - lamellar bone, mc - mesh-canal, msc - main sensory canal, pc - pore-canal, pco pore-canal opening, pl - pit-line, sb - spongy bone, sto - sensory tube opening, vc - vascular canal 


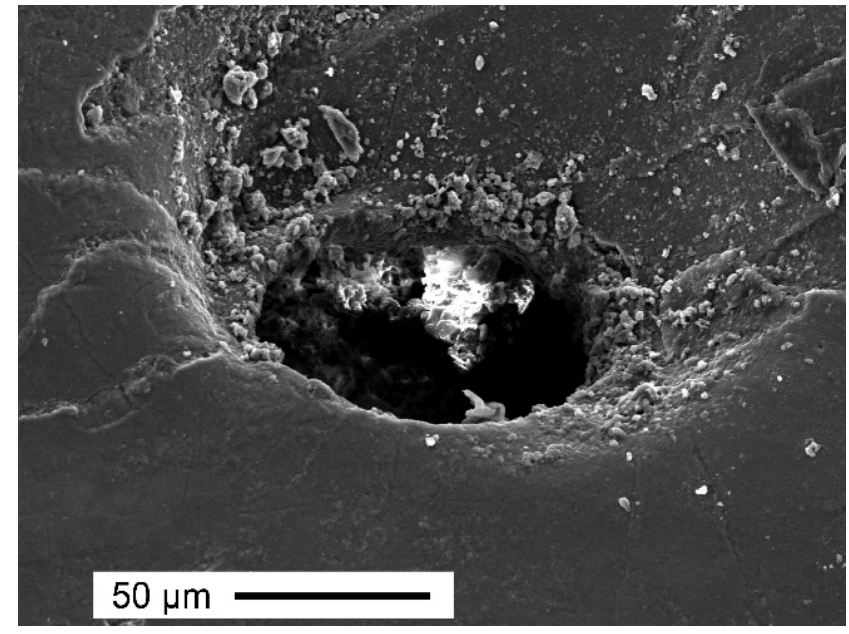

Fig. 6. Scanning electron micrograph of the cosmine surface with the sensory tube opening

correspond to the 150-250 $\mu \mathrm{m}$ measured in "osteolepiforms" (Thomson, 1977). All these values are considerably higher in porolepiforms and dipnoans (Thomson, 1977). The pore-canals of Porolepis Woodward, 1891 are approximately $250 \mu \mathrm{m}$ high, their openings reach 60-70 $\mu \mathrm{m}$ in diameter, and the distance between them is about $300 \mu \mathrm{m}$ (Thomson, 1977). In the dipnoan genus Ganorhynchus Traquair, 1873 the pore-canals are approximately $650 \mu \mathrm{m}$ high, their openings reach $400 \mu \mathrm{m}$ in diameter, and the distance between them is about $500 \mu \mathrm{m}$ (Thomson, 1977). Bemis and Northcutt (1992) recorded the diameter of dipnoan pore-canal openings as follows: $83 \mu \mathrm{m}$ in Sunwapta grandiceps Thomson, 1967; 20-160 $\mu \mathrm{m}$ with an average of $64 \mu \mathrm{m}$ in Dipterus valenciennesi Sedgwick and Murchison, 1829 and the openings as small as $45 \mu \mathrm{m}$ in Chirodipterus australis Miles, 1977.

Few comments have been made on the fine cosmine surface ornamentation between the pores. Chang and Smith (1992) recorded thin scalloped ridges of unknown character anterolateral to the pores in one specimen of Diabolepis Chang, 1984. A hexagonal pattern reflecting the arrangement and size of epithelial cells was observed in the dipnoans Chirodipterus australis Miles, 1977 (Smith, 1977) and Dipterus sp. (Schultze, 1977) using a magnification of 400 to 2000 times. The cosmine surface of the Moravian specimen shows a very fine pattern (Fig. 5C); nevertheless, the scanning electron microscope failed to reveal such a hexagonal pattern using corresponding magnifications (see Fig. 6). Säve-Söderbergh (1941) and Jarvik (1948) described an alternation of dark and light bands in the dentine layer of several (mainly black) specimens of "osteolepiform" tetrapodomorphs, especially if they were submerged in water or alcohol. A brown specimen from the Moravian Karst does not show these bands.

Dermal bones of "osteolepiform" tetrapodomorphs show a uniform overlap pattern (Jarvik, 1980). Overlapped areas at the anterior margin of the lateral extrascapular in the Moravian specimen could have served for articulation with the postparietal, tabular and probably also with the independently developed extratemporal bone (inferred from the tripartite anterior margin, see Säve-Söderbergh, 1933; see Fig. 4). However, bones of the postparietal shield and extrascapular series can vary in development even on both sides of one individual (Jarvik, 1948). A compound character of the lateral extrascapulars was recognized in a specimen of Osteolepis macrolepidotus Agassiz, 1835 with an independently devel- oped posteromedial part of this bone (Jarvik, 1948). On the other hand, a specimen of Thursius moy-thomasi Jarvik, 1948 lacking an independently developed median extrascapular is also known (Jarvik, 1948). The medial margin of the Moravian specimen lacks an overlapped area suggesting that the lateral extrascapulars must have overlapped the median extrascapular. This condition is usual in "osteolepiform" tetrapodomorphs (Jarvik, 1980). In porolepiforms, lateral extrascapulars are overlapped by the median one (Jarvik, 1980), and the situation in dipnoans is unclear because of the variability in the number of extrascapulars (Miles, 1977). The variability in shape of "osteolepiform" lateral extrascapulars was clearly demonstrated by Säve-Söderbergh (1933) in Middle Devonian specimens from Scotland. The pit-line can be present or absent in these bones, and this condition can also vary even on both sides of one animal (Jarvik, 1948). Numerous and evenly distributed openings of the main and supratemporal commissural canals in the Moravian specimen represent a feature known especially in younger forms of "osteolepiform" tetrapodomorphs such as Megalichthys Agassiz, 1835 or Eusthenopteron Whiteaves, 1881 from the Carboniferous and Permian successions (Jarvik, 1948). In Middle Devonian forms such as Thursius macrolepidotus (Sedgwick and Murchison, 1829) or Osteolepis macrolepidotus Agassiz, 1835, the branching of tubes rising from these canals is weak, and the tubule openings are often arranged in a single row (Jarvik, 1948). An intermediate condition was recorded e.g., in the lowermost Upper Devonian Latvius grewingki (Gross, 1933) with tubule openings arranged in double to triple rows (Jarvik, 1948).

"Osteolepiform" tetrapodomorphs have been obtained from freshwater and brackish water as well as marine strata, and the possibility of their anadromy has been discussed (see Thomson, 1969, 1980). According to Long et al. (1997), the sensory pore groups, which are distinctly developed mainly in specimens from freshwater deposits and absent in the marine Gogonasus andrewsae Long, 1985 could indicate salinity. The specimen from the Moravian Karst derives from a relatively deeper water environment with clearly marine fauna. Unfortunately, the lateral extrascapulars seem not to be suitable for diagnosis of the presence of sensory pore groups, so the suggestion by Long et al. (1997) cannot be confirmed nor disproved. Moreover, many "osteolepiforms" were obtained from red bed facies, the interpretation of which as regards salinity is still problematic (Laurin and Soler-Gijón, 2010).

The "osteolepiforms" have been subjected to numerous analyses (e.g., Long, 1985a, b; Ahlberg, 1991; Young et al., 1992; Ahlberg and Johanson, 1998; Coates and Friedman, 2010; Swartz, 2012; Witzmann and Schoch, 2012; Holland, 2013) leading to different interpretations of relationships within this group. Swartz (2012) used the term "osteolepiform" to encapsulate the grade of tetrapodomorphs, including the stem-based Canowindridae, Megalichthyiformes and Tristichopteridae.

Cosmine cover is completely absent in tristichopterids (e.g., Snitting, 2008), and canowindrids are supposed to be a Gondwanan group (Young et al., 1992). It is probable that the specimen from the Moravian Karst belongs to the megalichthyiforms sensu Swartz (2012). Young et al. (1992) described the shape of lateral extrascapulars in various "osteolepiform" groups (the character "C2: equilateral shape of extrascapulars" in their cladistic analysis). The condition of three-sided lateral extrascapulars almost meeting in the midline in canowindrids and megalichthyids vs. four-sided lateral extrascapulars well separated in the anterior midline in tristichopterids and "osteolepidids" such as Osteolepis Agassiz, 1835 or Gyroptychius M'Coy, 1848 was later discussed by 
Johanson and Ahlberg (1997). These authors pointed out that the lateral extrascapulars of the megalichthyid Cladarosymblema Fox et al., 1955 are four-sided and not three-sided as should be expected, and they revealed some contradiction between the descriptions and real shapes of these bones in some other genera. Johanson and Ahlberg (1997: p. 49) divided the character into two: "three sided lateral extrascapulars" and "lateral extrascapulars almost meeting in midline" and recommended further consideration. In this respect, the shape of the lateral extrascapular of the Moravian specimen is closer to megalichthyids than "osteolepidids". Nevertheless, it is necessary to treat such an assignment with caution. The distance between lateral extrascapulars in the Moravian specimen is not known. In addition, these features are generally rather problematic. Both groups are closely related (see Janvier et al., 2007) and comprise megalichthyiforms according to Swartz (2012).

The specimen described in this paper is the first recorded "osteolepiform" tetrapodomorph from the Paleozoic sequences of the Moravian Karst. Worldwide, other known Famennian cosmine-bearing "osteolepiforms" include e.g., Megapomus Vorobyeva, 1977 and Cryptolepis Vorobyeva, 1975 (Baltica Province), Megistolepis Obruchev, 1955 (Siberia Province) and Sterropterygion Thomson, 1972 (Laurentia Province) (see Lebedev and Zakharenko, 2010). A Famennian or possibly a Tournaisian age is also supposed for Medoevia lata Lebedev, 1995 which is from an unknown locality (Lebedev, 1995). Although these genera could also posses numerous and evenly distributed openings of sensory canals, we avoid assigning the Moravian specimen to any of them because the material comprises only one bone, and the lateral extrascapulars are known for their shape variability (see Säve-Söderbergh, 1933).

Its position at the Laurussian continental margin (Kalvoda and Bábek, 2010) and its presumed origin in a relatively deeper water environment on the bypass slope (see Weiner and Kalvoda, 2016) suggest assignment of this Moravian "osteolepiform" accompanied by chondrichthyans and "palaeoniscids" to the continental margin assemblage of the Baltica Province periphery sensu Lebedev et al. (2010). However, there is still a lack of detailed data on the fish fauna from the Ochoz section or from other Moravian Karst localities representing a similar mid Famennian environment. From the Czech Republic, remains of "osteolepiform" fish have been reported from limnic Upper Carboniferous and Lower Permian deposits (Zajíc, 2000, 2008; Štamberg and Zajíc, 2008). Isolated remains of Megalichthys nitens Fritsch, 1889 were recorded from the Carboniferous Kounov Member of the Slaný Formation of the Kladno-Rakovník Basin (Fritsch, 1889, 1893; Romer, 1945; Štamberg and Zajíc, 2008). Remains assigned to "Osteolepiformes" indet. are known from the Carboniferous Kounov Member of the Slaný Formation in the Mšeno-Roudnice and Kladno-Rakovník basins, the Klobouky Horizon of the Líně Formation in the Kladno-Rakovník Basin and the Permian Kalná Horizon of the Prosečné Formation in the Krkonoše Piedmont Basin (Štamberg and Zajíc, 2008).

\section{CONCLUSIONS}

To date, Devonian and Carboniferous deposits of the Moravian Karst (Moravo-Silesian Basin, Bohemian Massif) have yielded poor material of sarcopterygian fish, comprising only onychodontiforms (see Ginter, 1991; Smutná, 1994, 1996; Kumpan, 2013). The newly recorded subtriangular cosmine-covered right lateral extrascapular comes from the predominantly hemipelagic succession of the Famennian Kritiny Limestone of the Lišeň Formation. The combination of cosmine histological features including an absence of Westoll lines and buried odontodes, enamel/enameloid not extending into the pore-canals, pore-canals in a shape reminiscent of oast-house chimneys and the diameter of the pore-canal openings demonstrate an "osteolepiform" affinity. This assignment is supported by the lack of an overlapped area at the medial bone margin. The bone bears numerous evenly distributed openings of the sensory canals as is usual in stratigraphically later forms of "osteolepiform" tetrapodomorphs (Jarvik, 1948), and it lacks the lower mesh-canals present especially in some Middle Devonian forms (Thomson, 1977). The assignment to the "Megalichthyiformes" sensu Swartz (2012) seems to be most probable.

The associated fauna has a clearly marine character and contains e.g., clymenids, orthocone nautiloids, thin-shelled bivalves, trilobites, crinoids, conodonts, ostracods, chondrichthyans and "palaeoniscids". Compared to numerous "osteolepiforms" from red bed sequences, the Moravian specimen originates from the relatively deeper-water environment of the bypass slope (see Weiner and Kalvoda, 2016).

"Osteolepiforms" are recorded in the Paleozoic sequences of the Moravian Karst for the first time. In the Czech Republic, the remains of these tetrapodomorphs have previously only been reported from the Carboniferous and Permian limnic basins (Štamberg and Zajíc, 2008).

Acknowledgements. Thanks are due to O. Fatka and J. Kalvoda for their helpful comments. We are grateful to J. Štelcl for preparation of the scanning electron micrographs and T. Viktorýn for his kind help in the field. Cordial thanks are addressed to the reviewers J. Clack and M. Ginter for their useful suggestions. This contribution was supported by the Czech Science Foundation project GA14-18183S and Institute Research Plan RVO67985831.

\section{REFERENCES}

Ahlberg, P.E., 1991. A re-examination of sarcopterygian interrelationships, with special reference to the Porolepiformes. Zoological Journal of the Linnean Society, 103: 241-287.

Ahlberg, P.E., Johanson, Z., 1998. Osteolepiforms and the ancestry of tetrapods. Nature, 395: 792-794.

Bábek, O., Přikryl, T., Hladil, J., 2007. Progressive drowning of carbonate platform in the Moravo-Silesian Basin (Czech Republic) before the Frasnian/Famennian event: facies, compositional variations and gamma-ray spectrometry. Facies, 53: 293-316.

Bemis, W.E., Northcutt, R.G., 1992. Skin and blood vessels of the snout of the Australian lungfish, Neoceratodus forsteri, and their significance for interpreting of cosmine of devonian lungfishes. Acta Zoologica, 73: 115-139. 
Borgen, U.J., 1989. Cosmine resorption structures on three osteolepid jaws and their biological significance. Lethaia, 22: 413-424.

Borgen, U.J., 1992. The function of the cosmine pore canal system. In: Fossil fishes as living animals (ed. E. Mark-Kurik): 141-150. Academy of Sciences of Estonia, Tallinn.

Chang, M-M., Smith, M.M., 1992. Is Youngolepis a Porolepiform? Journal of Vertebrate Paleontology, 12: 294-312.

Clack, J.A., 2006. The emergence of early tetrapods. Palaeogeography, Palaeoclimatology, Palaeoecology, 232: 167-189.

Cloutier, R., Ahlberg, P.E., 1996. Morphology, characters, and the interrelationships of basal Sarcopterygians. In: Interrelationships of Fishes (eds. M.L.J. Stiassny, L.R. Parenti and G.D. Johnson): 445-479. Academic Press, San Diego.

Coates, M.I., Friedman, M., 2010. Litoptychus bryanti and characteristics of stem tetrapod neurocrania. In: Morphology, Phylogeny and Paleobiogeography of Fossil Fishes (eds. D.K. Elliott, J.G. Maisey, X. Yu and D. Miao): 389-416. Verlag Dr. F. Pfeil, München.

Finger, F., Hanžl, P., Pin, C., Quadt, A., Steyrer, H.P., 2000. The Brunovistulicum: Avalonian Precambrian at the eastern end of the Variscides. Geological Society Special Publications, 179: 103-112.

Fox, R.C., Campbell, K.S.W., Barwick, R.E., Long, J.A., 1995. A new osteolepiform fish from the Lower Carboniferous Raymond Formation, Drummond Basin, Queensland. Memoirs of the Queensland Museum, 38: 97-221.

Fritsch, A., 1889. Fauna der Gaskohle und der Kalksteine der Permformation Böhmes. II/4. F. Řivnáč: 93-114. Prag.

Fritsch, A., 1893. Fauna der Gaskohle und der Kalksteine der Permformation Böhmes. III/2. F. Řivnáč: 49-80. Prag.

Gross, W., 1956. Über Crossopterygier und Dipnoer aus dem baltischen Oberdevon im Zusammenhang einer vergleichenden Untersuchung des Porenkanalsystems paläozoischer Agnathen und Fische. Kungliga Svenska Vetenskapsakademiens Handlingar, Fjärde Serien, 5: 1-140.

Ginter, M., 1991. Ichthyoliths and fish fauna. Bulletin de la Société Belge de Géologie, 100: 74-76.

Hartenfels, S., 2011. Die globalen Annulata-Events und die Dasberg-Krise (Famennium, Oberdevon) in Europa und Nord-Afrika - hochauflösende Conodonten-Stratigraphie, Karbonat-Mikrofazies, Paläoökologie und Paläodiversität. Münstersche Forschungen zur Geologie und Paläontologie, 105: 17-527.

Hladil, J., 1992. Zonality of the Devonian sediments in Moravia (ČSFR). In: Proceedings of the 1st International Conference on the Bohemian Massif in 1988 (ed. Z. Kukal): 121-126. Czech Geological Survey, Prague.

Hladil, J., Melichar, R., Otava, J., Galle, A., Krs, M., Man, O., Pruner, P., Cejchan, P., Orel, P., 1999. The Devonian in the easternmost Variscides, Moravia: a holistic analysis directed towards comprehension of the original context. Abhandlungen der Geologischen Bundesanstalt, 54: 27-47.

Holland, T., 2013. Pectoral girdle and fin anatomy of Gogonasus andrewsae Long, 1985: Implications for tetrapodomorph limb evolution. Journal of Morphology, 274: 147-164.

Janvier, P., Clement, G., Cloutier, R., 2007. A primitive megalichthyid fish (Sarcopterygii, Tetrapodomorpha) from the Upper Devonian of Turkey and its biogeographical implications. Geodiversitas, 29: 249-268.

Jarvik, E., 1948. On the morphology and taxonomy of the Middle Devonian osteolepid fishes of Scotland. Kungliga Svenska Vetenskapsakademiens Handlingar, Tredje Serien, 25: 1-301.

Jarvik, E., 1980. Basic Structure and Evolution of Vertebrates. Academic Press, London.

Johanson, Z., Ahlberg, P.E., 1997. A new tristichopterid (Osteolepiformes: Sarcopterygii) from the Mandagery Sandstone (Late Devonian, Famennian) near Canowindra, NSW, Australia. Transactions of the Royal Society of Edinburgh: Earth Sciences, 88: 39-68.
Kalvoda, J., Bábek, O., 2010. The Margins of Laurussia in Central and Southeast Europe and Southwest Asia. Gondwana Research, 17: 526-545.

Kalvoda, J., Melichar, R., 1999. Paleozoic sediments of the Drahany Upland. Geolines, 8: 88-90.

Kalvoda, J., Bábek, O., Nehyba, S., Špaček, P., 1996. Upper Devonian and Lower Carboniferous calciturbidites from the Lesni lom quarry in Brno-Líšeň (southern part of the Moravian Karst) (in Czech with English abstract). Gelogické výzkumy na Moravě a ve Slezsku v roce 1995, 3: 98-100.

Kalvoda, J., Bábek, O., Malovaná, A., 1999. Sedimentary and biofacies record in calciturbidites at the Devonian-Carboniferous boundary in Moravia (Moravian-Silesian Zone, Middle Europe). Facies, 41: 141-158.

Kalvoda, J., Melichar, R., Bábek, O., Leichmann, J., 2002. Late Proterozoic-Paleozoic tectonostratigraphic development and paleogeography of Brunovistulian terrane and comparison with other terranes at the SE margin of Baltica-Laurussia. Journal of the Czech Geological Society, 47: 81-102.

Kalvoda, J., Babek, O., Fatka, O., Leichmann, J., Melichar, R., Nehyba, S., Spacek, P., 2008. Brunovistulian terrane (Bohemian Massif, Central Europe) from Proterozoic to late Paleozoic: A review. International Journal of Earth Sciences (Geologische Rudschau), 97: 497-518.

Kumpan, T., 2013. Preliminary report on the occurrence of the ichthyoliths in the Upper Famennian and Lower Tournaisian of the Moravian Karst (in Czech). Geologické výzkumy na Moravě a ve Slezsku, 20: 136-140.

Laurin, M., Soler-Gijón, R., 2010. Osmotic tolerance and habitat of early stegocephalians: indirect evidence from parsimony, taphonomy, palaeobiogeography, physiology and morphology. Geological Society Special Publications, 339: 151-179.

Lebedev, O.A., 1995. Morphology of a new osteolepidid fish from Russia. Bulletin du Muséum national d'histoire naturelle. Section C, Sciences de la terre, paléontologie, géologie, mineralogy, 17: 287-341.

Lebedev, O.A., Lukševičs, E., Zakharenko, G.V., 2010. Palaeozoogeographical connections of the Devonian vertebrate communities of the Baltica Province. Part II. Late Devonian. Palaeoworld, 19: 108-128.

Lebedev, O.A., Zakharenko, G.V., 2010. Global vertebrate-based palaeozoogeographical subdivision for the Givetian-Famennian (Middle-Late Devonian): endemism-cosmopolitanism spectrum as an indicator of interprovincial faunal exchanges. Palaeoworld, 19: 186-205.

Long, J.A., 1985a. A new osteolepidid fish from the Upper Devonian Gogo Formation, Western Australia. Records of the Western Australian Museum, 12: 361-377.

Long, J.A., 1985b. The structure and relationships of a new osteolepiform fish from the Late Devonian of Victoria, Australia. Alcheringa, 9: 1-22.

Long, J.A., Barwick, R.E., Campbell, K.S.W., 1997. Osteology and functional morphology of the osteolepiform fish Gogonasus andrewsae Long, 1985, from the Upper Devonian Gogo Formation, Western Australia. Records of the Western Australian Museum, Supplement No. 53: 1-89.

Long, J.A., Gordon, M.S., 2004. The greatest step in vertebrate history: A paleobiological review of the fish-tetrapod transition. Physiological and Biochemical Zoology, 77: 700-719.

Meinke, D.K., 1984. A review of cosmine: Its structure, development, and relationship to other forms of the dermal skeleton in osteichthyans. Journal of Vertebrate Paleontology, 4: 457-470.

Miles, R.S., 1977. Dipnoan (lungfish) skull and the relationships of the group: a study based on new species from the Devonian of Australia. Zoological Journal of the Linnean Society, 61: 1-328.

Ørvig, T., 1969. Cosmine and cosmine growth. Lethaia, 2: 241-260.

Rez, J., Melichar, R., Kalvoda, J., 2011. Polyphase deformation of the Variscan accretionary wedge: an example from the southern part of the Moravian Karst (Bohemian Massif, Czech Republic). Geological Society Special Publications, 349: 223-235. 
Romer, A.S., 1945. The Late Carboniferous vertebrate fauna of Kounova (Bohemia) compared with that of the Texas redbeds. American Journal of Science, 243: 417-442.

Rosen, D.E., Forey, P.L., Gardiner, B.G., Patterson, C., 1981 Lungfishes, tetrapods, paleontology, and plesiomorphy. Bulletin of the American Museum of Natural History, 167: 159-276.

Rzehak, A., 1910. Der Brüner Clymenienkalk. Zeitschrift des Mährischen Landesmuseums, 10: 149-216.

Säve-Söderbergh, G., 1933. The dermal bones of the head and the lateral line system in Osteolepis macrolepidotus Ag.: With remarks on the terminology of the lateral line system and on the dermal bones of certain other crossopterygians. Nova Acta Regiae Societatis Scientiarum Upsaliensis, Ser. IV, 9: 1-129.

Säve-Söderbergh, G., 1941. Notes on the dermal bones of the head in Osteolepis macrolepidotus Ag. and the interpretation of the lateral line system in certain primitive Vertebrates. Zoologiska Bidrag frín Uppsala, 20: 523-541.

Sire, J.-Y., Donoghue, P.C.J., Vickaryous, M.K., 2009. Origin and evolution of the integumentary skeleton in non tetrapod vertebrates. Journal of Anatomy, 214: 409-440.

Schultze, H.P., 1977. Ausgangsform und Entwicklung der rhombischen Schuppen der Osteichthyes (Pisces). Paläontologische Zeitschrift, 51: 152-168.

Schultze, H.P., 1986. Dipnoans as Sarcopterygians. In: The Biology and Evolution of Lungfishes (eds. W.E. Bemis, W.W. Burggren and N.E. Kemp): 39-74. Alan R. Liss, Inc., New York.

Smith, M.M., 1977. The microstructure of the dentition and dermal ornament of three dipnoans from the Devonian of Western Australia: A contribution towards dipnoan interrelations, and morphogenesis, growth and adaptation of the skeletal tissues. Philosophical Transactions of the Royal Society of London. Series B, Biological Sciences, 281: 29-72.

Smutná, S., 1994. New data on Upper Devonian fish fauna in Moravia (in Czech). Geologické výzkumy na Moravě a ve Slezsku v roce 1993, 1: 64.

Smutná, S., 1996. Upper Devonian and Lower Carboniferous fish fauna in Moravia (in Czech). Geologické výzkumy na Moravě a ve Slezsku v roce 1995, 3: 122-127.

Snitting, D., 2008. Morphology, taxonomy and interrelationships of tristichopterid fishes (Sarcopterygii, Tetrapodomorpha). Acta Universitatis Upsaliensis. Digital Comprehensive Summaries of Uppsala Dissertations from the Faculty of Science and Technology, 421. Uppsala.

Swartz, B., 2012. A marine stem-tetrapod from the Devonian of Western North America. PLoS ONE, 7: 1-11; e33683. doi:10.1371/journal.pone.0033683

Štamberg, S., Zajíc, J., 2008. Carboniferous and Permian faunas and their occurrence in the limnic basins of the Czech Republic. Muzeum východních Čech v Hradci Králové. Hradec Králové.

Thomson, K.S., 1969. The environment and distribution of Paleozoic sarcopterygian fishes. American Journal of Science, 267: 457-464.

Thomson, K.S., 1975. On the biology of cosmine. Yale University Peabody Museum of Natural History Bulletin, 40: 1-59.
Thomson, K.S., 1977. On the individual history of cosmine and a possible electroreceptive function of the pore-canal system in fossil fishes. In: Problems in Vertebrate Evolution (eds. S.M. Andrews, R.S. Miles and A.D. Walker): 247-270. Linnean Society Symposium Series 4, Academic Press, New York.

Thomson, K.S., 1980. The ecology of Devonian lobe-finned fishes In: The Terrestrial Environment and the Origin of Land Vertebrates (ed. A.L. Panchen): 187-222. Academic Press, London.

Thomson, K.S., 1993. The origin of the tetrapods. American Journal of Science, 239-A: 33-62.

Weiner, T., 2013. Stratigraphy and facies of some Famennian and lower Carboniferous outcrops in the southern part of the Moravian Karst (in Czech). Master thesis, Masaryk University, Brno, Czech Republic.

Weiner, T., Kalvoda, J., 2013. Annulata event from a pit-quarry near Ochoz u Brna - remarks on conodont biostratigraphy (Famennian, Moravian Karst) (in Czech). Geologické výzkumy na Moravě a ve Slezsku, 20: 141-144.

Weiner, T., Kalvoda, J., 2016. Biostratigraphic and sedimentary record of the Annulata Events in the Moravian Karst (Famennian, Czech Republic). Facies, 62: 1-25.

Westoll, T.S., 1936. On the structures of the dermal ethmoid shield of Osteolepis. Geological Magazine, 73: 157-171.

Witzmann, F., Schoch, R.R., 2012. A megalichthyid sarcopterygian fish from the Lower Permian (Autunian) of the Saar-Nahe Basin, Germany. Geobios, 45: 241-248.

Young, G.C., Long, J.A., Ritchie, A., 1992. Crossopterygian fishes from the Devonian of Antarctica: systematic, relationships and biogeographic significance. Records of the Australian Museum, Supplement ,14: 1-77.

Zajíc, J., 2000. Vertebrate zonation of the non-marine Upper Carboniferous - Lower Permian basins of the Czech Republic. Courier Forschungsinstitut Senckenberg, 223: 563-575.

Zajíc, J., 2008. The main Late Carboniferous and Early Permian lake fish communities of the Czech Republic. In: Faunas and Palaeoenvironments of the Late Palaeozoic - Special Publication to $5^{\text {th }}$ Symposium on Permo-Carboniferous Faunas (eds. S. Štamberg and J. Zajíc): 53-54. Museum of Eastern Bohemia at Hradec Králové, Hradec Králové.

Zhu, M., Yu, X., Wang, W., Zhao, W., Jia, L., 2006. A primitive fish provides key characters bearing on deep osteichthyan phylogeny. Nature, 441: 77-80.

Zhu, M., Wang, W., Yu, X., 2010. Meemannia eos, a basal sarcopterygian fish from the Lower Devonian of China - expanded description and significance. In: Morphology, Phylogeny and Paleobiogeography of Fossil Fishes (eds. D.K. Elliott, J.G. Maisey, X. Yu and D. Miao): 199-214. Verlag Dr. F. Pfeil, München.

Zukalová, V., Chlupáč, I., 1982. Stratigrafická klasifikace nemetamorfovaného devonu moravskoslezské oblasti (in Czech). Časopis pro mineralogii a geologii, 27: 225-241. 